\title{
Potential and Mechanisms for Stable C Storage in the Post-Mining Soils under Long-Term Study in Mitigation of Climate Change
}

\author{
Aneta Kowalska 1,*(D), Marek Kucbel ${ }^{2} \mathbb{D}$ and Anna Grobelak ${ }^{1}$ \\ 1 Faculty of Infrastructure and Environment, Czestochowa University of Technology, Brzeznicka 60a, \\ 42-200 Czestochowa, Poland; anna.grobelak@pcz.pl \\ 2 Centre ENET-Energy Units for Utilization of Non-Traditional Energy Sources, VSB` $\_$Technical University \\ of Ostrava, 17, Listopadu 15/2172, 70800 Ostrava-Poruba, Czech Republic; marek.kucbel@vsb.cz \\ * Correspondence: aneta.kowalska@pcz.pl
}

Citation: Kowalska, A.; Kucbel, M.; Grobelak, A. Potential and Mechanisms for Stable C Storage in the Post-Mining Soils under Long-Term Study in Mitigation of Climate Change. Energies 2021, 14, 7613. https://doi.org/10.3390/ en14227613

Academic Editor: Dalia Štreimikienè

Received: 24 October 2021

Accepted: 10 November 2021

Published: 15 November 2021

Publisher's Note: MDPI stays neutral with regard to jurisdictional claims in published maps and institutional affiliations.

Copyright: (c) 2021 by the authors. Licensee MDPI, Basel, Switzerland. This article is an open access article distributed under the terms and conditions of the Creative Commons Attribution (CC BY) license (https:/ / creativecommons.org/licenses/by/ $4.0 /)$.

\begin{abstract}
Carbon storage in soil increases along with remediation of post-mining soils. Despite many studies on the issue of carbon sequestration in soils, there is a knowledge gap in the potential and mechanisms of $\mathrm{C}$ sequestration in post-mining areas. This research, including nuclear magnetic resonance analysis, determines the soil organic carbon formation progress in a long-term study of limestone (S1), and lignite (S2) post-mining soil under different remediation stages. The main remediation target is reforesting; however, S2 was previously amended with sewage sludge. The study showed that for $\mathrm{S} 1$, the O-alkyl groups were the dominant fraction in sequestered soil. However, for S2, increased fractions of acetyl- $C$ and aromatic $C$ groups within remediation progress were observed. The remediation of S1 resulted in improved hydrophobicity and humification; however, the decrease in aromatic groups' formation and $\mathrm{C} / \mathrm{N}$ ratio was noted. For S2, we noticed an increase for all indicators for sequestered $C$ stability, which has been assigned to the used sewage sludge in remediation techniques. While both post-mining soils showed huge potential for $\mathrm{C}$ sequestration, S2 showed much higher properties of sequestered $C$ indicating its higher stabilization which can suggest that soils non-amended with sewage sludge (S1) require more time for stable storage of $C$.
\end{abstract}

Keywords: carbon sequestration; remediation of post-mining soil; climate change; post-mining soil; soil organic carbon (SOC); hydrophobicity; aromaticity; humification

\section{Introduction}

The fate of carbon in the environment is presently one of the main focuses worldwide. The alarming concentrations of carbon dioxide $\left(\mathrm{CO}_{2}\right)$ in the atmosphere are considered to be responsible for the observed global warming and climate changes, as $\mathrm{CO}_{2}$ is one of the greenhouse gases (GHG). On the other hand, soils and forests are the most representative $\mathrm{C}$ pool, thus carbon sequestration in the soil may be the main tool aimed for the mitigation or slowing down of climate changes by lowering the $\mathrm{CO}_{2}$ concentration in the atmosphere and stable storage in the soil [1]. The efficiency of the carbon sequestration is strictly determined by the soil quality [2]. Unfortunately, human activity was instrumental in the worsening quality of the soil worldwide throughout the severe environmental transformation. In particular, mining is considered to be highly destructive for the environment [3]. The processes of topsoil removal carried out during opencast mining cause severe destruction in the ecosystem, making its restoration difficult. It is caused by the destruction of the soil microclimate, deterioration of the water regime, water pollutions, as well as deleting of the organic matter which determines fertility, and thus the quality and productivity of the soil including its ability to sequestrate carbon, and finally, destroying the soil health [4]. The remediation of the post-mining soils is challenging, especially due to the necessity to recreate the natural soil functionality. Nevertheless, the increasing areas with degraded 
soils force the recovery of the damaged area. It is important not only in the aspect of the soil, but it also has immense value for the whole environment as the remediation of post-mining soil allows for the enhancement of carbon sequestration lowering climate change.

The functions of the soil carbon are not limited to climate change purposes. Carbon $(\mathrm{C})$ in the soil plays an essential role in building all organic compounds, and thus, influencing soil fertility. Organic $\mathrm{C}$ in the soil determines all soil properties including biological, chemical, and physical, and moreover, $\mathrm{C}$ is involved in the nutrients cycle in the environment [5]. Organic carbon in the soil hinders the leaching of the mineral fraction from the soil allowing the proper growth and development of plants and influencing biodiversity [6]. Soil organic carbon (SOC) also affects, among others, the sorption capacity, filtration capacity [7], and soil structure [8], and therefore C takes an essential role in the soil formation processes [9]. In properly functioning soil, the C-cycle is undisturbed and there are many $\mathrm{C}$ inputs, such as plant residues, fertilizers, secondary sources of animal origin (animals excrements, residues of soil fauna), etc. However, the post-mining areas represent a very limited $C$ pool in the soil. In post-mining soil and during the first stages of remediation, soil carbon is provided by organic fertilizers and also from the soil C sequestration, and within the remediation progress, the number of $C$ sources [3] and $C$ sequestration increases [10].

The organic carbon in the soil is heterogenous, since a part of it is stable with a large half-life period and part of SOC is quickly mineralized by soil microorganisms. According to Dignac et al. [11], there are three different conceptual $C$ pools in the soil concerning their degradation rate: labile $C$, intermediate $C$, and stable $C$. The main source of labile and intermediate $C$ is litter and roots, and its turnover is day-year (for labile $C$ ), and years-decades (for intermediate $C$ ). The stable $C$ is retrieved from the labile $C$ and intermediate $C$, and its turnover range is between decades and centuries. The majority of SOC consists of the stable $\mathrm{C}$, and may be found in aggregates and/or absorbed on mineral surfaces. The alkyl-C and aromatic $\mathrm{C}$ are considered to be the most stable fraction of SOC, while O-alkyl and carbonyl $\mathrm{C}$ are quickly mineralized. The mechanisms of their formation in a long-term study should be helpful for the better understanding of SOC sequestration mechanisms. The SOC has been widely described by Dignac et al.; however, they indicated the essential need for long-term monitoring of experimental sites. Therefore, in the literature of the subject, there are no studies on the mechanisms and potential of post-mining soils for SOC sequestration which has been a struggle in this paper.

According to the estimations of Blume et al. [12], roughly $80 \%$ of the terrestrial soil organic carbon (SOC) stock are located in the soil structure and even $2060+/-215 \mathrm{Pg} \mathrm{C}$ may be located in the topsoil layer of $2 \mathrm{~m}$ [13]. Kanzler et al. [14] indicate that any change in soil carbon stock may cause severe changes in the global C-cycle, thus suggesting the huge potential of the soil in the mitigation of climate change. Fox et al. [15] noticed that postmining areas have a huge potential for carbon sequestration, which is the confirmation of proper soil restoration. In Poland, the remediation of the post-mining soil is usually carried out via reforestation, providing large opportunities for improving carbon sequestration [3]. While the potential of post-mining soil for capturing atmospheric carbon has been widely studied, there is a lack of knowledge of the issue of the mechanisms of the stable storage of captured carbon in post-mining soils. In this research, we studied the forms of carbon stored in post-mining soils at different stages of remediation to determine the mechanisms of the carbon sequestration of post-mining areas.

\section{Materials and Methods}

\subsection{Characteristic of Post-Mining Soils and Sampling}

In the current study, two different open-cast post-mining soils recultivated with different methods have been studied: limestone post-mining soil (S1) recultivated with embarkment obtained in the mining process, and lignite post-mining soil (S2) recultivated with sewage sludge obtained in a wastewater treatment plant. The remediation of the 
studied post-mining soil is directed for reforestation (Figure 1). Both places are located in Poland.

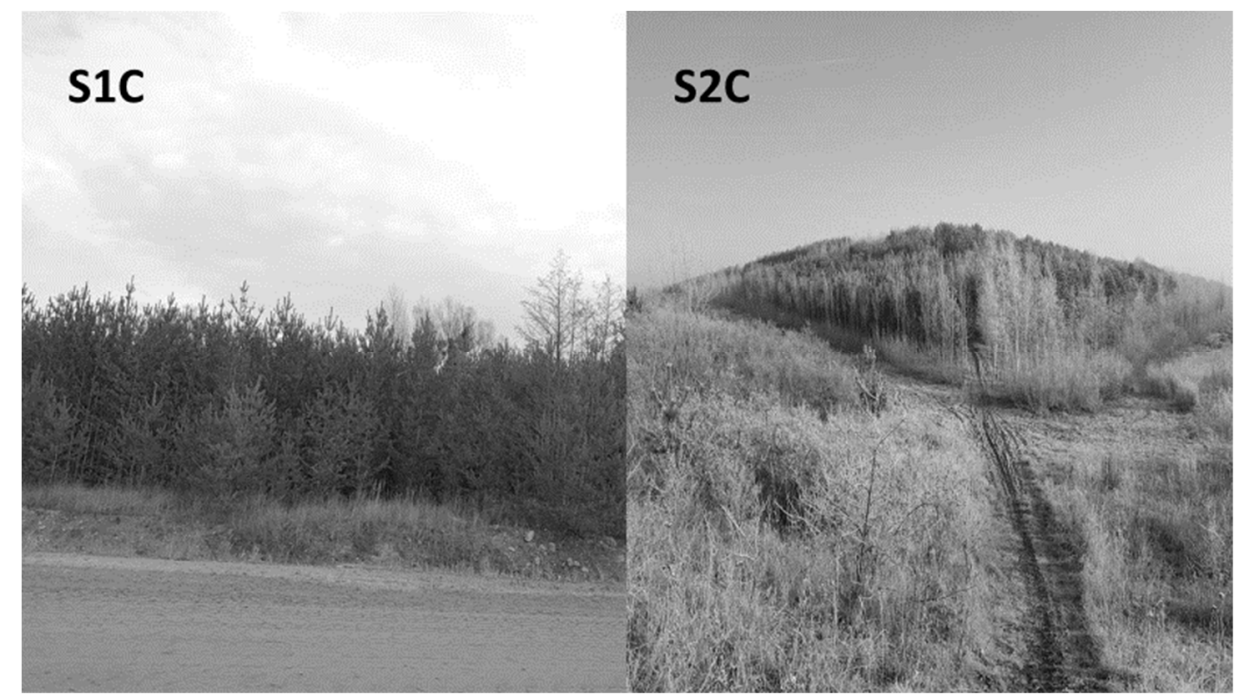

Figure 1. Selected studied soils (S1C - soil collected from the limestone open-cast mining area remediated with embarkment obtained during the mining process-12 years old; S2C—soil collected from the lignite open-cast mining area remediated with sewage sludge-13 years old).

Intensive exploitation of limestone is conducted at S1. The reforestation recultivation at the S1 area has been conducted since 1984. The following tree species are mainly used for reforestation at S1: Pinus silvestris, Betula verrucose, and Alnus incana. They constitute forecrop trees with phytomelioration and pioneering properties.

The S2 area is located near the lignite and brown coal opencast mine in Poland, which is one of the largest in Europe. The recultivation is conducted with the use of sewage sludge obtained in a treatment plant. The sewage sludge contains $>10 \%$ solids and is combined with plant seeds in the amount of $2 \%$ by weight of the mixture. The mass of sludge with seeds falling to the surface stabilizes them at the place of sowing (discharge). The following plant seeds are mainly used for planting in the S2 area: Trifolium repens, Trifolium pratense, Lolium multiflorum, Lolium perenne, and Agrostis stolonifera. All plants are characterized by the ability to compete with the introduced forest crops. Thirty $t$ of fermented and hydrated sewage sludge were used per 1 ha. The reforestation recultivation at the S2 area is conducted with the following trees: Alnus glutinosa, Gaertn, Quercus robur, and Pinus silvestris.

For each studied area, we selected different remediated places located at the postmining area which differs from the recultivation advancement. The recultivation periods were similar for both areas. The characteristics of the studied areas are described in detail in Table 1. Sampling was conducted in November 2019 in similar weather conditions at both post-mining areas, excluding the influence of weather conditions in the course of the study. At each of the studied places, 12 soil samples were collected at an equal distance and evenly between each other. Soil cane was used to collect the samples. Samples (1L volume each) were collected from the $20 \mathrm{~cm}$ of the topsoil. Sampling was conducted in the same scheme for each area. For laboratory analyses, the averaged samples have been prepared to ensure the representativeness, quality, and accuracy of analyses for all studied places. 
Table 1. Characteristic of studied post-mining areas (S1-soil collected from the limestone open-cast mining area remediated with embarkment obtained during the mining process; S2-soil collected from the lignite open-cast mining area remediated with sewage sludge; subsequent letters A-D mean different remediated areas located at the same mine).

\begin{tabular}{cccc}
\hline Soil & $\begin{array}{c}\text { Area of the } \\
\text { Recultivated Soil [ha] }\end{array}$ & $\begin{array}{c}\text { Year of the Remediation } \\
\text { Beginning [Year] }\end{array}$ & $\begin{array}{c}\text { The Reclamation Period at } \\
\text { the Time of Sampling [Years] }\end{array}$ \\
\hline S1A & 4.0 & 2019 & 1 \\
S1B & 10.0 & 2014 & 6 \\
S1C & 3.5 & 2008 & 12 \\
S1D & 6.0 & 2002 & 18 \\
S2A & 6.0 & 2019 & 1 \\
S2B & 3.0 & 2013 & 7 \\
S2C & 5.5 & 2007 & 13 \\
S2D & 7.0 & 2002 & 18 \\
\hline
\end{tabular}

\subsection{Soil Chemical Analyses}

For each studied area, soil samples were air-dried, grounded, and sifted with a diameter of $<2 \mathrm{~mm}$.

Each soil sample was studied for total carbon (TC) according to the Polish standard PN-ISO 10694:2002. The total carbon was performed after dry combustion with Multi N/C H 1300 Analytik Jena analyzer.

The soil samples were studied for total Kjeldahl nitrogen (TN) according to the Polish Standard (PN-ISO 11261:2002). The TN was measured in soil samples after mineralization with $95 \% \mathrm{H}_{2} \mathrm{SO}_{4}$. The mineralization was performed with catalysts mixture $\mathrm{K}_{2} \mathrm{SO}_{4}+$ $\mathrm{Cu}_{2} \mathrm{SO}_{4}$. The alkalization was performed with $33 \% \mathrm{NaOH}$. Moreover, the $\mathrm{C} / \mathrm{N}$ ratio was calculated.

The total phosphorus was measured for all studied areas according to the Egner-Reihm method [16].

The $\mathrm{pH}$ values of the soil samples were measured in distilled $\mathrm{H}_{2} \mathrm{O}$ and $1 \mathrm{M} \mathrm{KCl}$ using a standard laboratory pH-meter (Elmetron CP-401, Thane, India) according to ISO 10390:2005.

\subsection{SOC Chemical Composition}

For representative samples of all studied areas, the carbon forms were examined with 13C NMR using spectrometer NMR $600 \mathrm{MHz}$ (Bruker, Poland). The study was performed with $100 \mathrm{mg}$ of ground and sifted soil with a diameter of $<2 \mathrm{~mm}$. The studies were taken using CP MAS $3.2 \mathrm{~mm}$ probe in $300 \mathrm{~K}$ with sample rotation of $8 \mathrm{kHz}$. Ceramic rotors with a diameter of $3.2 \mathrm{~mm}$ were fully filled with soil samples. The obtained 13C NMR spectra were divided into 4 groups: alkyl-C $\left(\mathrm{C}_{\mathrm{AL}}\right)(0-45 \mathrm{ppm}), \mathrm{O}-\mathrm{alkyl} \mathrm{C}_{\mathrm{OAL}}(45-110 \mathrm{ppm})$, aromatic $C\left(C_{A R}\right)(110-160 \mathrm{ppm})$, and carbonyl $C\left(\mathrm{C}_{\mathrm{CN}}\right)(160-210 \mathrm{ppm})$. The calculations of hydrophobicity (HB), aromaticity, and humification [17] of the soils were also conducted. For the calculation of hydrophobicity (HB), the following equation was used: $\mathrm{HB}=\left(\mathrm{C}_{\mathrm{AL}}+\mathrm{C}_{\mathrm{AR}}\right) /\left(\mathrm{C}_{\mathrm{OAL}}+\mathrm{C}_{\mathrm{CN}}\right)$. The aromaticity was calculated as follows: $\mathrm{C}_{\mathrm{AR}} /\left(\mathrm{C}_{\mathrm{AL}}+\mathrm{C}_{\mathrm{OAL}}+\mathrm{C}_{\mathrm{AR}}+\mathrm{C}_{\mathrm{CN}}\right)$ [18]. The degree of organic matter decomposition (humification) was calculated according to the equation: $\mathrm{C}_{\mathrm{AL}} / \mathrm{C}_{\mathrm{OAL}}[19,20]$.

\subsection{Statistical Analyses}

Origin 8 Pro software was used for statistical analyses. All data have been shown as the mean values $(n=3)$ with a standard deviation. A one-way ANOVA was used to compare parameters among the soils collected from the same post-mining area: separately for S1, and separately for S2. All correlation coefficients significant at $p<0.05$ were calculated. 


\section{Results}

Carbon is considered as one of the most important elements for the evaluation of soil quality. In the studied soils, we observed different carbon performances during soil reclamation. For the soil S1, we noticed that total carbon concentration shows an increasing trend reaching up to $17.79 \mathrm{~g} \mathrm{C} \mathrm{kg}^{-1} \mathrm{~d} . \mathrm{m}$. in 20 years (S1D), in contrast to the shortest recultivation period (S1A), where the concentration of total C is $13.54 \mathrm{~g} \mathrm{C} \mathrm{kg}^{-1} \mathrm{~d}$.m. (Table 2). For the post-mining soil recultivated with sewage sludge, we noticed an opposite trend, as the total carbon concentration in S2 decreases with the recultivation time. However, we noticed that carbon decreases strongly in the first 5 years, and then remains stable through the next 7 years, and in the next 11 years increases (S2D) exceeding TC content in S2A. The initial decline in the TC content could be caused by the increased microbial activity and the subsequent increase may result from the stabilization of the soil ecosystem followed by the sequestration of soil organic carbon.

Table 2. Characteristic of studied soils (S1-soil collected from the limestone open-cast mining remediated with embarkment obtained during the mining process; S2—soil collected from the lignite open-cast mining remediated with sewage sludge; subsequent letters A-D mean different remediated areas located at the same mine). Mean values $\pm \mathrm{SD}, n=3$. Different letters above the columns indicate significant differences between tested treatments $(p<0.05)$ according to Tukey's test. Small and large letters indicate separate analyses for both soils.

\begin{tabular}{|c|c|c|c|c|c|}
\hline Soil & $\begin{array}{c}\text { Total C } \\
\text { [g kg }{ }^{-1} \text { d.m.] }\end{array}$ & $\begin{array}{c}\text { P Total } \\
{\left[\mathrm{mg} 100 \mathrm{~g}^{-1} \text { d.m.] }\right.}\end{array}$ & $\begin{array}{c}\text { N Kjeldahl } \\
\text { [g kg-1 d.m.] }\end{array}$ & $\mathrm{pH}(\mathrm{KCl})$ & $\mathrm{pH}\left(\mathrm{H}_{2} \mathrm{O}\right)$ \\
\hline S1A & $13.54 \pm 1.431 \mathrm{a}$ & $1.11 \pm 0.012 \mathrm{a}$ & $5.47 \pm 0.032 \mathrm{a}$ & $7.47 \pm 0.109 \mathrm{a}$ & $7.41 \pm 0.096 \mathrm{a}$ \\
\hline S1B & $14.40 \pm 0.667 b$ & $0.76 \pm 0.074 b$ & $7.98 \pm 0.010 b$ & $7.32 \pm 0.143 \mathrm{a}$ & $7.33 \pm 0.087 \mathrm{a}$ \\
\hline S1C & $14.06 \pm 0.530 \mathrm{ab}$ & $1.27 \pm 0.047 \mathrm{a}$ & $7.40 \pm 0.039 c$ & $7.44 \pm 0.126 \mathrm{a}$ & $7.58 \pm 0.132 b$ \\
\hline S1D & $17.79 \pm 0.833 c$ & $0.97 \pm 0.272 \mathrm{ab}$ & $7.90 \pm 0.020 b$ & $7.33 \pm 0.053 \mathrm{a}$ & $7.38 \pm 0.082 \mathrm{a}$ \\
\hline S2A & $3.59 \pm 0.264 \mathrm{~A}$ & $7.51 \pm 0.076 \mathrm{~A}$ & $4.84 \pm 0.020 \mathrm{~A}$ & $7.23 \pm 0.111 \mathrm{~A}$ & $7.14 \pm 0.123 \mathrm{~A}$ \\
\hline S2B & $2.40 \pm 0.246 \mathrm{~B}$ & $4.20 \pm 0.257 \mathrm{~B}$ & $1.12 \pm 0.039 \mathrm{~B}$ & $7.04 \pm 0.121 \mathrm{~A}$ & $7.00 \pm 0.055 \mathrm{~A}$ \\
\hline S2C & $2.58 \pm 0.646 \mathrm{~B}$ & $1.91 \pm 0.012 \mathrm{C}$ & $1.18 \pm 0.039 \mathrm{~B}$ & $7.22 \pm 0.022 \mathrm{~A}$ & $6.88 \pm 0.131 \mathrm{~A}$ \\
\hline S2D & $6.89 \pm 0.104 C$ & $6.18 \pm 0.338 \mathrm{D}$ & $2.94 \pm 0.020 \mathrm{C}$ & $7.34 \pm 0.054 \mathrm{~A}$ & $7.57 \pm 0.156 \mathrm{~B}$ \\
\hline
\end{tabular}

In both types of soil S1 and S2, we noticed a very low amount of phosphorus (P). In soil S1 during the reclamation, the P content remains at a similar and very low level oscillating approximately $1 \mathrm{mg} 100 \mathrm{~g}^{-1} \mathrm{dm}$. (Table 2). In contrast, for the soil S2 we noticed a slightly higher $\mathrm{P}$ concentration in comparison to S1; however, both soils are very poor in $\mathrm{P}$. The content of P in S2 initially showed a lowering tendency and increased significantly for S2D in comparison to S2C.

The nitrogen $(\mathrm{N})$ content similar to the TC showed an opposite behavior in the reclamation of studied soils. We observed an increase in Kjeldahl N for soil S1 in the first 6 years, which remains at a similar level for the next 12 years. For the soil S2, we noticed a significant decrease of nitrogen content followed by an increase. Nevertheless, for all tested areas for S2, very low amounts of nitrogen content were noted.

The $\mathrm{pH}$ in $\mathrm{KCl}$ was similar for all tested soils and oscillated approximately 7.20. The $\mathrm{pH}$ in distilled water showed slight differences among the remediation period and for S1 ranged between $7.33 \pm 0.087$ and $7.58 \pm 0.132$, and for S2 between $6.88 \pm 0.133$ and $7.57 \pm 0.156$.

The stability of $\mathrm{C}$ sequestered in the soils strongly depends on its forms present in the soil. Alkyl-C (0-45 ppm), due to the presence of strong chemical bonds $C-C$, is considered as the most stable form of soil organic carbon [21]. For soil S1, we noticed a significant increase ( $24.4 \%$ for S1A and $33.8 \%$ for S1D) in the percentage share of SOC in this form throughout the period of 18 years (Table 3). For soils S2, we observed a much higher increase in the percentage share of SOC as alkyl C (28.4\% for S2A and $46.9 \%$ for S2D, indicating an almost doubling of alkyl C in SOC in 18 years). The presence of aromatic C (110-160 ppm) in the soil derives from the lignin, tannins, and charcoal and is difficult to decompose [21]. For studied post-mining soil, an opposite trend was noted in the share of aromatic $\mathrm{C}$ in SOC. Over 18 years, aromatic C increased significantly in soil S1. For the S2 site, the \% 
share of aromatic C in SOC was much higher in S2D in comparison to S2A. For both soils, this fraction of SOC was predominantly aryl C. O-alkyl C (45-110 ppm) derived from the polysaccharides such as cellulose and hemicellulose but also from proteins. The carbonyl C (160-220 ppm) derives from aliphatic esters, carbonyl groups and amide carbonyls, which are easily decomposable [22]. For the soil S1, O-alkyl C slightly increased with the reclamation period, while for S2 it emphatically decreased (over a 2 times decline). For both soils, carbohydrates predominated in the O-alkyl C fraction of the SOC. In turn, carbonyl C showed a falling trend for both studied soils through 18 years of remediation.

Table 3. A percentage of carbon forms in studied soils [\%] (S1—soil collected from the limestone open-cast mining area remediated with embarkment obtained during the mining process; S2—soil collected from the lignite open-cast mining area remediated with sewage sludge; subsequent letters A-D mean a different remediated area located at the same mine).

\begin{tabular}{|c|c|c|c|c|c|c|c|c|c|c|c|}
\hline \multirow{2}{*}{ Soil } & \multirow{2}{*}{$\begin{array}{c}\begin{array}{c}\text { Alkyl C } \\
(0-45 \text { ppm })\end{array} \\
\text { Alkyl C }\end{array}$} & \multicolumn{4}{|c|}{$\begin{array}{c}\text { O-Alkyl C } \\
\text { (45-110 ppm) }\end{array}$} & \multicolumn{3}{|c|}{$\begin{array}{c}\text { Aromatic C } \\
(110-160 \mathrm{ppm})\end{array}$} & \multicolumn{3}{|c|}{$\begin{array}{c}\text { Carbonyl C } \\
(160-220 \mathrm{ppm})\end{array}$} \\
\hline & & N-alkyl/Methoxyl C & Carbohydrate C & diO-Alkyl C & Total & Aryl C & O-Aryl C & Total & Carboxyl/Amide C & Ketone/Aldehyde & Total \\
\hline S1A & $24.4 \pm 0.92$ & $5.8 \pm 0.03$ & $27.6 \pm 0.94$ & $10.8 \pm 0.31$ & $44.2 \pm 1.03$ & $12.3 \pm 0.82$ & $3.7 \pm 0.02$ & $16.0 \pm 0.95$ & $10.1 \pm 0.03$ & $5.3 \pm 0.01$ & $15.4 \pm 0.98$ \\
\hline $\begin{array}{l}S 1 \mathrm{~A} \\
\text { S1B }\end{array}$ & $\begin{array}{l}2.4 \pm 0.92 \\
30.1 \pm 0.85\end{array}$ & $\begin{array}{l}3.8 \pm 0.03 \\
7.0 \pm 0.02\end{array}$ & $\begin{array}{l}28.6 \pm 0.94 \\
28.0 \pm 1.22\end{array}$ & $\begin{array}{l}10.8 \pm 0.31 \\
8.4 \pm 0.03\end{array}$ & $\begin{array}{l}43.4 \pm 1.22 \\
43.4 \pm 1.22\end{array}$ & $\begin{array}{l}12.3 \pm 0.82 \\
12.7 \pm 0.73\end{array}$ & $\begin{array}{l}3.7 \pm 0.02 \\
3.4 \pm 0.04\end{array}$ & $\begin{array}{l}16.0 \pm 0.95 \\
16.1 \pm 0.89\end{array}$ & $\begin{array}{l}1.1 \pm 0.03 \\
7.4 \pm 0.05\end{array}$ & $\begin{array}{l}3.3 \pm 0.01 \\
2.9 \pm 0.01\end{array}$ & $\begin{array}{l}13.4 \pm 0.98 \\
10.4 \pm 0.93\end{array}$ \\
\hline $\mathrm{S} 1 \mathrm{C}$ & $37.1 \pm 0.93$ & $9.1 \pm 0.08$ & $27.9 \pm 2.03$ & $7.8 \pm 0.05$ & $44.9 \pm 0.94$ & $7.7 \pm 0.044$ & $2.1 \pm 0.02$ & $9.8 \pm 0.64$ & $7.3 \pm 0.06$ & $0.9 \pm 0.01$ & $11.2 \pm 0.65$ \\
\hline S1D & $33.8 \pm 1.22$ & $5.4 \pm 0.03$ & $28.3 \pm 1.29$ & $13.9 \pm 0.02$ & $47.5 \pm 2.11$ & $7.0 \pm 0.12$ & $0.3 \pm 0.01$ & $7.3 \pm 0.13$ & $8.30 \pm 0.03$ & $3.1 \pm 0.01$ & $8.5 \pm 0.031$ \\
\hline $\mathrm{S} 2 \mathrm{~A}$ & $28.4 \pm 0.83$ & $5.2 \pm 0.02$ & $24.0 \pm 1.04$ & $16.7 \pm 0.04$ & $45.9 \pm 1.76$ & $10.7 \pm 1.00$ & $2.2 \pm 0.02$ & $13.0 \pm 0.93$ & $10.4 \pm 0.98$ & $2.4 \pm 0.01$ & $18.8 \pm 1.03$ \\
\hline S2B & $\begin{array}{l}29.0 \pm 2.02 \\
29.0\end{array}$ & $\begin{array}{l}4.6 \pm 0.06 \\
4.06\end{array}$ & $23.0 \pm 0.95$ & $11.0 \pm 0.01$ & $28.6 \pm 0.98$ & $12.3 \pm 0.93$ & $3.5 \pm 0.01$ & $15.7 \pm 0.74$ & $10.9 \pm 0.38$ & $5.8 \pm 0.02$ & $16.7 \pm 0.954$ \\
\hline $\mathrm{S} 2 \mathrm{C}$ & $35.1 \pm 1.22$ & $5.8 \pm 0.03$ & $20.6 \pm 0.84$ & $11.2 \pm 0.01$ & $37.6 \pm 2.11$ & $12.3 \pm 0.73$ & $3.8 \pm 0.01$ & $16.2 \pm 1.09$ & $6.5 \pm 0.03$ & $4.6 \pm 0.03$ & $11.1 \pm 0.74$ \\
\hline S2D & $46.9 \pm 2.31$ & $7.6 \pm 0.05$ & $\begin{array}{l}9.0 \pm 0.04 \\
9.3 \pm 0.05\end{array}$ & $5.0 \pm 0.02$ & $21.9 \pm 1.03$ & $16.1 \pm 0.99$ & $5.3 \pm 0.02$ & $21.4 \pm 1.21$ & $6.5 \pm 0.01$ & $\begin{array}{l}4.0+0.00 \\
3.3+0.02\end{array}$ & $9.8+0.36$ \\
\hline
\end{tabular}

The dominant fractions for all studied post-mining soil remediated with embarkment S1 obtained in the mining were those of O-alkyl C (45-110 ppm) and alkyl C (0-45 ppm) (Figure 2). The spectra of 13C CP MAS NMR show a significant increase of the peak for the chemical region of alkyl-C (0-45 ppm) for the soil with the recultivation time in comparison to the soil at the beginning of recultivation (S1A). For the chemical shift region of alkyl C for all studied S1 soil, there is a strong signal for methylene (approximately 35 ppm). For S1, in the chemical shift region of O-alkyl C (45-110 ppm), we noticed two separate peaks: approximately 75 ppm (indicating cellulose), and approximately 105-110 ppm (indicating mainly hemicellulose and other carbohydrates). For all studied S1 soils, in the spectrum of 13C CP MAS NMR, there is a much weaker peak in the chemical shift region of carbonyl $C$ (approximately $175 \mathrm{ppm}$ ). According to the spectra for post-mining soils remediated with sewage sludge, we noticed significant differences in the chemical composition of the SOC. For the location with the oldest remediation (S2D), we observed only one, and a very strong dominant peak in the chemical shift region of alkyl-C (0-45 ppm). The studied soils at the other stages of remediation (S2A, S2B, S2C) showed a high variety in the chemical composition of SOC. For those soils, there are two dominant peaks in the chemical shift region of alkyl-C (0-45 ppm) the highest for $35 \mathrm{ppm}$ (methylene), and for the O-alkyl C region similarly to the S1 soil. The existence of such a pattern for the post-mining soil under 18 years of recultivation (S2D) may be caused by the stabilization of the SOC and sequestering of carbon in the alkyl $\mathrm{C}$ form followed by an increase in total carbon content for this soil (Table 2).

Hydrophobicity indicates an affinity of the soil matter to the water particles, and thus, has an impact on soil wetting and retention of water, and consists of an important feature for the evaluation of SOC quality [23]. For soil S1, we have not observed a clear tendency for hydrophobicity with the age of remediation (Figure 3). For S1B and S1C, the hydrophobicity increased while I decreased for S1D. For soil S2, we observed a gradual growing tendency with the remediation time, where it increased over 3 times for S2D (18 years of remediation) in comparison to S2A (1 year of remediation). It is considered that higher hydrophobicity improves the long-lasting aggregate stability of SOM [24,25]. Moreover, this increase in hydrophobicity in remediated soils may strongly affect the water availability to plants and also increase the surface runoff and thus increase the susceptibility of the soil to secondary erosion [26]. A reason for the much higher hydrophobicity of S2 after 18 years of remediation may be the presence of organic complexes formulated in the soil. The increased hydrophobicity strongly limits the leachability of organic matter, and thus positively influences soil organic carbon sequestration in the soil. 

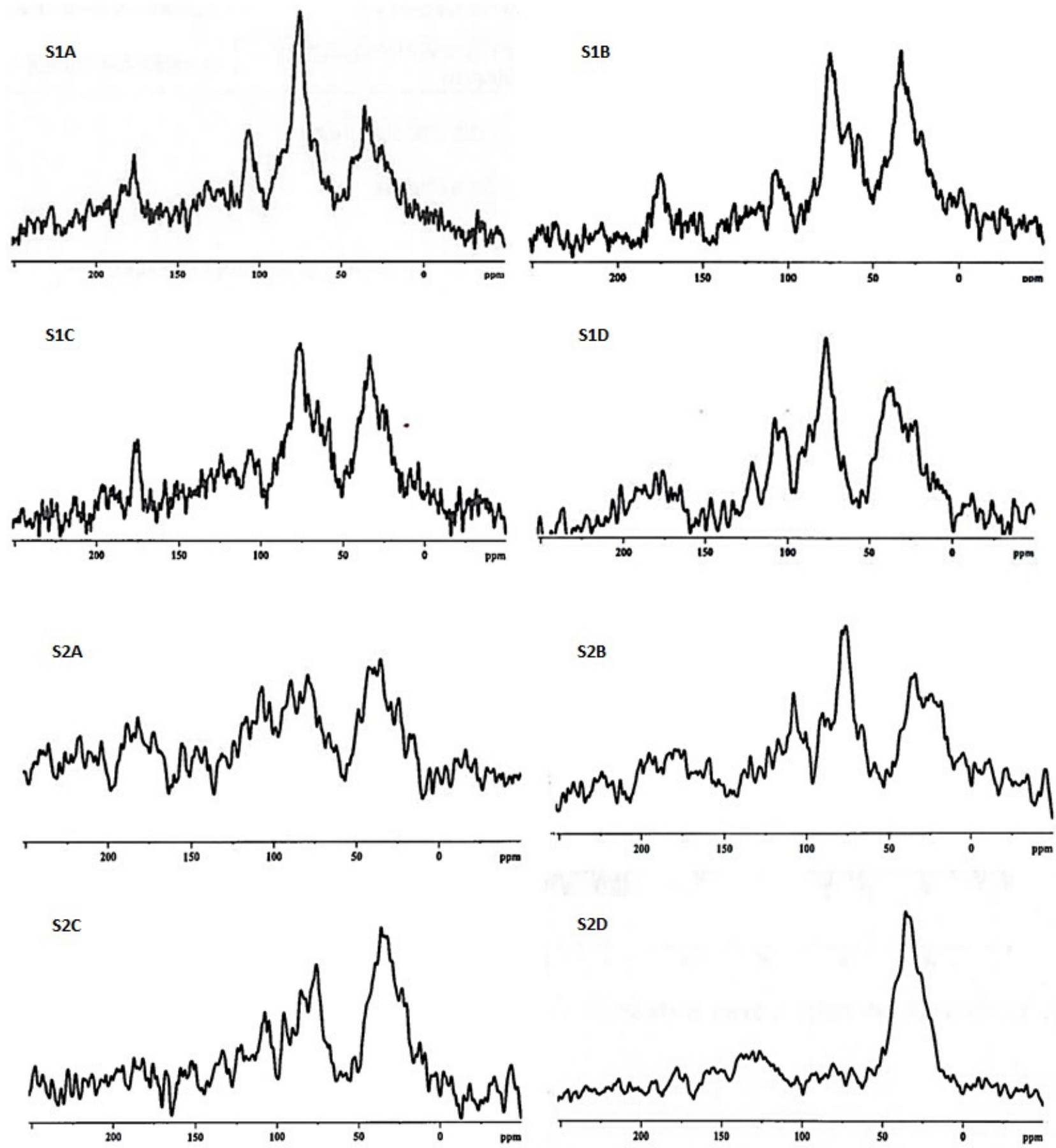

Figure 2. Spectra of 13C CP MAS NMR for studied soils (S1—soil collected from the limestone open-cast mining remediated with embarkment obtained during the mining process; S2—-soil collected from the lignite open-cast mining remediated with sewage sludge; subsequent letters (A-D) mean a different remediated area located at the same mine).

Aromatic structures are considered to be difficult for decomposition, and they also have a long half-life in soil. Such a feature makes aromatic compounds a valuable tool for $\mathrm{C}$ sequestration [27]. Aromaticity did not change for the first 6 years in S1, while in the next years of remediation it decreased significantly after 12 years (S1C), and finally reached over a 2 times decrease after 18 years of remediation (S1D) in comparison to the 1 year of remediation (S1A) (Figure 4). The opposite tendency was observed for S2, where aromaticity increased gradually and was much higher after 18 years of reclamation in comparison to the soil under 1 year of reclamation (S2A). We noticed statistically important differences between different ages of remediation in soil S2. We observed that the remediation with 
an addition of organic matter (sewage sludge) showed better influence on aromaticity, whereas remediation with embarkment caused a decrease in aromaticity. The increase in this feature in $\mathrm{S} 2$ has a positive impact on $\mathrm{C}$ sequestration.

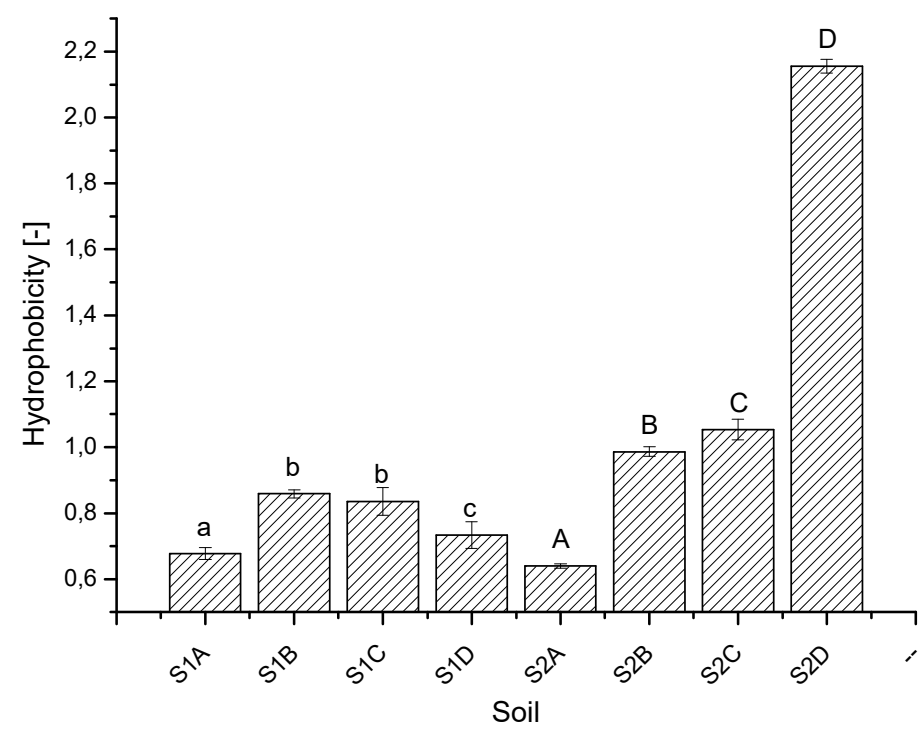

Figure 3. Hydrophobicity for studied soils (S1—soil collected from the limestone open-cast mining remediated with embarkment obtained during the mining process; S2-soil collected from the lignite open-cast mining remediated with sewage sludge; subsequent letters A-D mean a different remediated area located at the same mine). Mean values $\pm \mathrm{SD}, n=3$. Different letters above the columns indicate significant differences between tested treatments $(p<0.05)$ according to Tukey's test. Small and large letters indicate a separate analysis for both soils.

Humification, together with aromaticity and hydrophobicity, consist of an important feature in assessing the quality of $C$ stock. In our observations, humification increased gradually for both soils but in S1D finally decreased (Figure 5). However, the change in humification for S1D in comparison to S1D shows statistically significant differences indicating after all on its increase. The humification for S2D (18 years of reclamation) was almost 2.5 times higher in comparison to the S2A (1 year of reclamation). Humification, as an indicator for the susceptibility for organic matter decomposition for both studied soils, indicated the positive influence for $\mathrm{C}$ sequestration.

The ratio of $\mathrm{C}$ and $\mathrm{N}$ is considered as an important tool for controlling $\mathrm{C}$ sequestration in the soil. For the mining soil remediated with embarkment achieved in the mining process, the $\mathrm{C} / \mathrm{N}$ ratio in the first 6 years significantly decreased and remained stable for the next 6 years (Figure 6). Nevertheless, we noticed the statistically important differences for the next 6 years, where $\mathrm{C} / \mathrm{N}$ increased slightly. However, it still remained at a much lower level in comparison to the S1A. The likely reason for this was an increase in C content in the soil along the remediation period. For soil S2 we observed a strong increase in the $\mathrm{C} / \mathrm{N}$ ratio in the first 7 years which remained stable for the next 11 years. After 18 years of reclamation, the $\mathrm{C} / \mathrm{N}$ ratio was over 3 times higher in comparison to the soil under 1 year of reclamation. Therefore, we noticed good plant growth in the later stages of remediation, thus, we assume that the reason for the increase of the $\mathrm{C} / \mathrm{N}$ ratio in $\mathrm{S} 2$ may be that plants potentially uptake $\mathrm{N}$ at later stages of remediation. The increase in the $\mathrm{C} / \mathrm{N}$ ratio is a desirable effect for $\mathrm{C}$ sequestration purposes because it needs a longer time to decompose [28]. Therefore, the soils with a higher $\mathrm{C} / \mathrm{N}$ ratio are considered to be characterized by longer half-lives that promote longer $C$ persistence in the soil, and thus supports $C$ sequestration. 


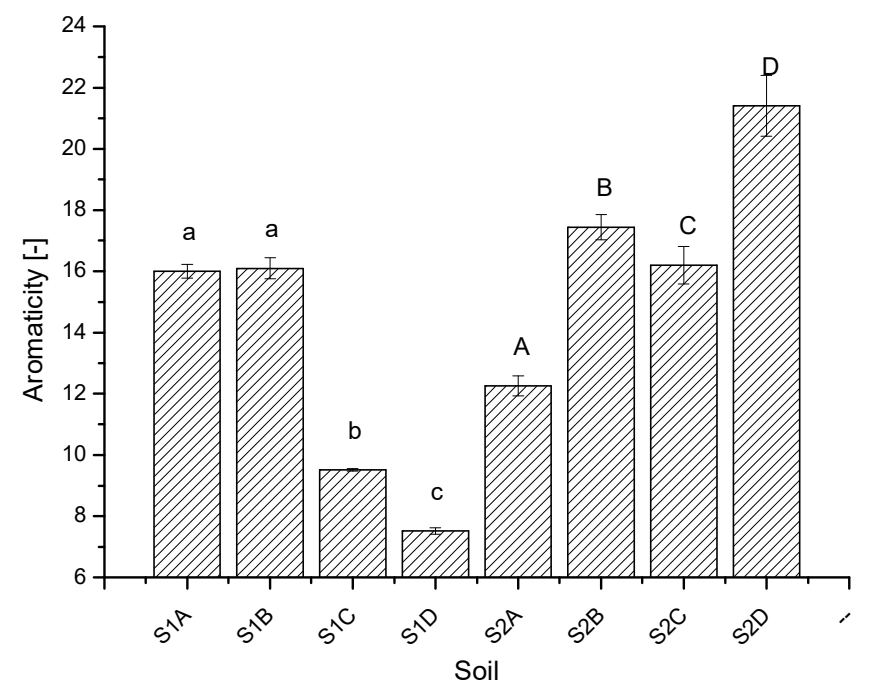

Figure 4. Aromaticity for studied soils (S1-soil collected from the limestone open-cast mining remediated with embarkment obtained during the mining process; S2-soil collected from the lignite open-cast mining remediated with sewage sludge; subsequent letters A-D mean a different remediated area located at the same mine). Mean values $\pm S D, n=3$. Different letters above the columns indicate significant differences between tested treatments $(p<0.05)$ according to Tukey's test. Small and large letters indicate a separate analysis for both soils.

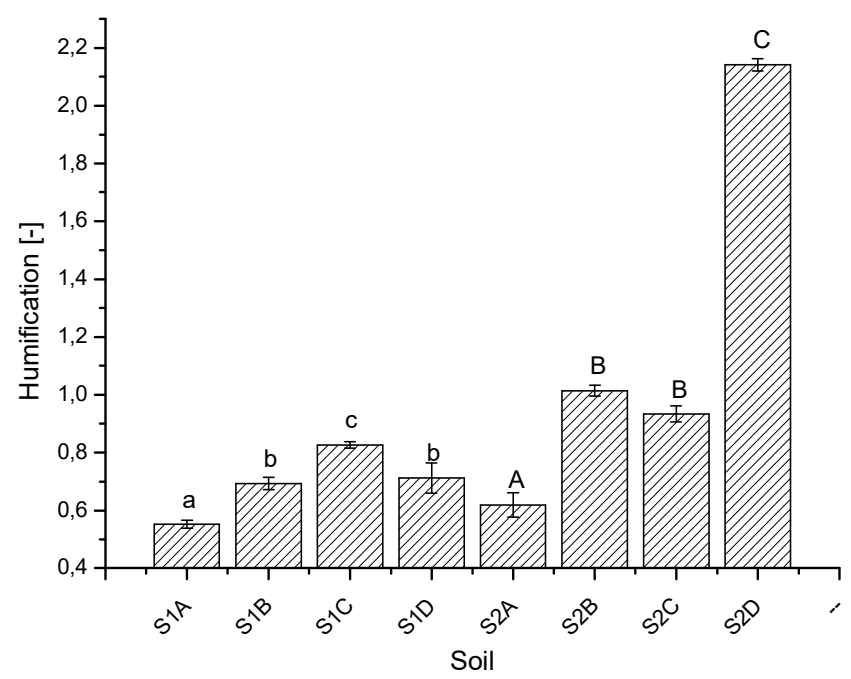

Figure 5. Humification for studied soil (S1—soil collected from the limestone open-cast mining remediated with embarkment obtained during the mining process; S2-soil collected from the lignite open-cast mining remediated with sewage sludge; subsequent letters A-D mean a different remediated area located at the same mine). Mean values $\pm \mathrm{SD}, n=3$. Different letters above the columns indicate significant differences between tested treatments $(p<0.05)$ according to Tukey's test. Small and large letters indicate a separate analysis for both soils. 


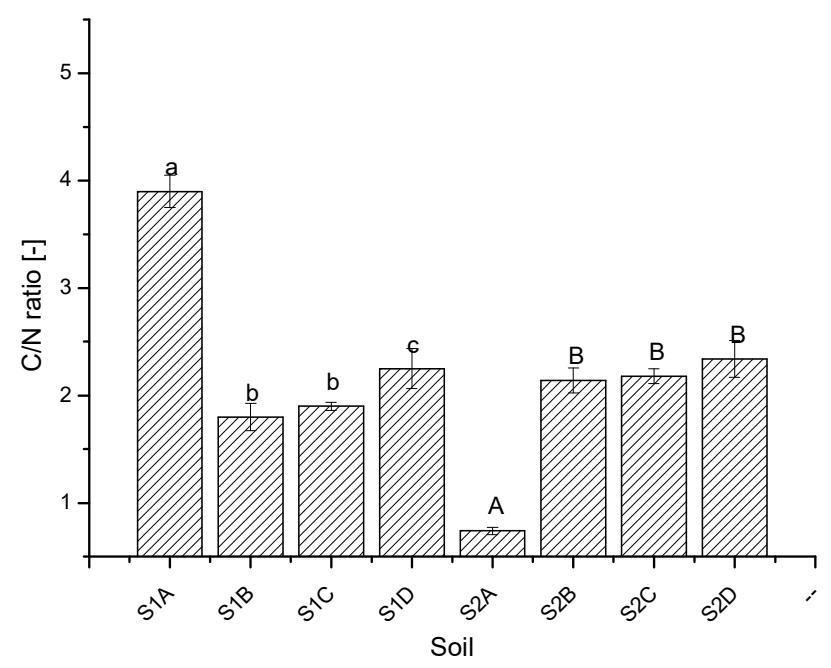

Figure 6. $\mathrm{C} / \mathrm{N}$ ratio for studied soils (S1-soil collected from the limestone open-cast mining remediated with embarkment obtained during the mining process; S2-soil collected from the lignite open-cast mining remediated with sewage sludge; subsequent letters A-D mean a different remediated area located at the same mine). Mean values $\pm \mathrm{SD}, n=3$. Different letters above the columns indicate significant differences between tested treatments $(p<0.05)$ according to Tukey's test. Small and large letters indicate a separate analysis for both soils.

\section{Discussion}

\subsection{Total Carbon, Nitrogen, Phosphorus}

Mining is a major contributor to the emission of GHGs. The open-mining processes lead to severe destruction in the soil and its degradation, which are considered important emitters of $\mathrm{CO}_{2}$ into the atmosphere. The remediation of the post-mining soil, besides improving soil quality, is considered to drive $\mathrm{C}$ sequestration, and thus lower the $\mathrm{CO}_{2}$ release from the soil. Therefore, the carbon content is crucial for soil quality and fertility, and its sequestration may bring dual benefits for both the soil quality, as well as for the quality of the atmosphere. Mine lands are extreme examples of the soils, which are poured into organic matter, and thus, are considered to have a significant potential carbon sink. In the study, we observed improved soil TC for both studied soils after 18 years of remediation. However, we noticed a much higher increase in TC for soil remediated with sewage sludge located at the lignite post-mining area (S2) in comparison to soils remediated with embarkment located at the limestone post-mining area (S1) collected during mining processes. Such observations indicate the supported influence of the application of additional organic matter such as sewage sludge for storing carbon in the soil. Other studies show that sewage sludge [3] or compost application on post-mining soils influences the increase of TC in the soil [29]. The study of Singh et al. [30] on coal mine soil also indicated an increase in carbon stock with the duration of the reclamation process.

Therefore, in the present study, we noticed a very low P content in both studied areas. A similar decreasing trend for the content of $\mathrm{P}$ was noticed in the other studies on the post-mining areas conducted by Placek et al. [31] in the study on the limestone mining area remediated with sewage sludge. Previously conducted studies suggested that the application of organic matter improves the content of available $P$ in the soil, which is a result of supported microbial activity [32]. A similar study also showed an increase in total $\mathrm{P}$ along with the remediation of post-mining areas [33].

The observed different trends for $\mathrm{N}$ content along remediation for limestone and lignite mine soils may have resulted from the remediation method and strongly improved microbial activity by the addition of organic matter in the remediation method applicated for S2. Hu et al. [34], in their observation on non-amended and amended post-mining soil, indicated an increase in $\mathrm{N}$ concentration in amended soil $\left(0.65 \mathrm{mg} \mathrm{kg}^{-1}\right)$ in comparison to non-amended soil $\left(0.31 \mathrm{mg} \mathrm{kg}^{-1}\right)$. Therefore, they suggested that soil $\mathrm{N}$ availability 
is lower for post-mining soils in contrast to non-mining soils. They proposed that soil amendment under post-mining remediation effect in the increase of $\mathrm{N}$ availability. Another study indicated a TN increase along with remediation age [33].

\subsection{Carbon Composition in the Remediated Post-Mining Soils}

Carbon composition has a strong impact on the stability and storage of $\mathrm{C}$ in the soil. The presence of non-labile $C$ increases soil potential for stable $C$ sequestration, whereas labile $C$ is easily decomposable and does not persist long in the soil due to the microbial activity, and thus its half-life is much shorter than non-labile fractions. For $\mathrm{C}$ sequestration purposes, mainly compounds with the binding C-C and aromatic compounds are promoted to persist for a long time in the soil $[35,36]$. To determine the potential $C$ sequestration of post-mining soil during the remediation process we analyzed carbon composition in all tested soils throughout the 13C NMR method. The achieved results showed an increased percentage share of alkyl-C (0-45 ppm) and O-alkyl C (45-110 ppm) for post-mining limestone soil (S1), whereas aromatic C (110-160 ppm), and carbonyl C (160-210 ppm) decreased with the age of remediation. Improved alkyl-C (0-45 ppm) content in SOC as a $C$ fraction with a long half-life increases the potential to sequestrate $C$ [37]. Simultaneously, the increased fraction of a labile fraction of O-alkyl C (45-110 ppm), and its domination among $\mathrm{C}$ forms lowers the ability of the post-mining limestone soil (S1) for stable storage of sequestered carbon. As previously reported, aromatic C (110-160 ppm) consists of a fraction that is not easy to decompose, thus its presence in the soil is supposed to positively drive the $C$ sequestration [21]. A gradual decrease in aromatic C (110-160 ppm) noticed for the post-mining limestone soil (S1) along 18 years of remediation combined with increased O-alkyl C (45-110 ppm) decreases the stability of sequestered C. The finding for postmining lignite soils showed an improvement in a non-labile $C$ (alkyl-C 0-45 ppm, aromatic C 110-160 ppm) with a simultaneous fall in labile C (O-alkyl C 45-110 ppm, carbonyl C 160-210 ppm). The proportions of non-labile and labile $C$ in the studied post-mining lignite soil are promising for a stable $\mathrm{C}$ sequestration.

\subsection{The Influence of the Remediation Post-Mining Soils on the Stability of SOC}

The ratio of hydrophobic $\mathrm{C}$ and hydrophilic $\mathrm{C}$ indicates hydrophobicity of the soil and consists of a sum of unoxidized atoms of carbon [20]. This ratio is considered to be an important indicator of SOM quality [23]. The value of hydrophobicity of the SOM results from the presence of aliphatic $\mathrm{C}-\mathrm{H}$ founded in methyl, methylene, and methine groups [38]. SOM hydrophobicity determinates microbial activity in principal for soil rich in clay particles [39]. Therefore, this feature helps to control the water affinity, soil moisture, and thus, has an impact on SOM resistance to biodegradation. Due to the presence of a hydrophobic coating on soil particles, the ratio of hydrophobic $C$ and hydrophilic $C$ strongly influences the retention of water in the soil [40]. The hydrophobicity strongly influences the wettability and adsorption as well [41]. It is considered that the leading factor influencing soil hydrophobicity is organic matter. Therefore, higher hydrophobicity is considered to protect SOM against microbial decomposition, and thus improves its persistence and storage in the soil [42]. Among others, complex organic acids are considered to cover particles of soil increasing soil hydrophobicity [40]. For post-mining limestone soil (S1), we initially observed a slight increase in hydrophobicity, however, finally, it started to decrease but was still a little bit higher in comparison to the starting point. For postmining lignite soil, we observed an increase in hydrophobicity within the remediation, which supports SOC against decomposition and prolongs storage of the SOM. Other studies confirmed that hydrophobic soils have a better ability to persistently store organic matter in comparison to hydrophilic soils [43]. Therefore, it is also considered that higher hydrophobicity may contribute to the lower mineralization of labile forms of SOC, and thus increases SOC [19].

Along with the remediation of limestone post-mining areas, the aromaticity of the soil decreased. The observed lowering aromatic C may influence the stability of stored SOC as 
aromatic C shows the ability for long persistence in the soil [27]. The significant increase in aromaticity in lignite post-mining soil for the remediation period is promising for $C$ sequestration. Other studies showed that aromaticity increased with the age of reclamation and was improved in the soil reclaimed instead of unclaimed soil [20]. A similar increase in the aromaticity of the coal mine soil has been observed by Singh et al. [30] along with the reclamation.

Higher humification indicates better resistance of $\mathrm{C}$ stock for microbial degradation, and thus supports $C$ sequestration. It is connected with the formation of humic substances, mainly humic acids and fulvic acids, that show large resistance for degradation [44,45]. They play an important role in the global carbon and nitrogen cycle. Therefore, humic substances have many supporting functions for soil such as promoting plant growth [46], seed germination [47], and microorganisms' activity [48]. In the present study for both limestone post-mining soil (S1) and lignite post-mining soil (S2), the humification was higher in comparison to the shorter period of remediation. The increase in humification with the age of remediation increases humic substances in the soil and has an influence on SOC stability. Humic substances, due to aromatic cores and interaction with mineral substances, are highly protected against microbial attack, thus, humic substances belong to the difficult decomposable substances [49]. Thus, the increase in humification along the remediation at studied post-mining soil indicates a promising role for increasing SOC stability. Therefore, it has been suggested previously that higher humification linked with higher hydrophobicity improves the resistance of organic carbon for decomposition [50]. We noticed such a combined change in both mining soils along with the remediation age. These observations suggest improved stability of sequestered carbon indicating the possible ability of the limestone and lignite post-mining soil to indirectly limit climate change.

The $\mathrm{C} / \mathrm{N}$ ratio is considered a basic indicator for the transformation of SOM. Our finding showed a decrease in the $\mathrm{C} / \mathrm{N}$ ratio along with remediation of limestone post-mining soil, whereas for lignite post-mining soil, it increased strongly. Other studies indicated a decrease in the $\mathrm{C} / \mathrm{N}$ ratio with the soil age [51]. Therefore, Hüblová and Frouz [1] studied the influence of the type of tree on soil carbon storage in post-mining soil under reforestation. They noticed the negative correlation between the $C / N$ ratio and $C$ sequestration. They suggested that $C$ sequestration is improved under trees that produce a litter with high $\mathrm{N}$ content and low $\mathrm{C} / \mathrm{N}$ ratio.

In limestone post-mining soil, the sequestration of carbon stock is based mainly on the O-alkyl C storage which has a rather low half-time in the soil. However, along with the remediation the $C$ sequestration is directed to the production of alkyl-C which is relatively stable in the soil. Such changes influenced the increase in the hydrophobicity and humification, while the aromaticity and $\mathrm{C} / \mathrm{N}$ ratio is decreasing. That suggests that the stable storage of carbon in such soil needs more time to produce a more stable $\mathrm{C}$ fraction. The mechanisms of SOC sequestration in lignite post-mining soils seem to be based on the formation of the Alkyl-C and aromatic C, rather than O-alkyl C and carbonyl C. Such a pattern influenced the higher hydrophobicity, aromaticity, humification, and $\mathrm{C} / \mathrm{N}$ ratio. The better formation of stable $C$ in lignite post-mining soil rather than in limestone postmining soil is probably closely related to the application of sewage sludge into a lignite post-mining soil, which caused more effective soil remediation.

\section{Conclusions}

The aim of this research was to become familiar with the potential and mechanisms of the SOC sequestration in post-mining soils at different stages of remediation. This study confirmed the high potential of post-mining soils for $C$ sequestration purposes. The longterm study showed that the formation of non-labile $C$ within the remediation is more visible for the lignite post-mining area (an increase of alkyl C in $18.5 \%$ ), while the limestone postmining soil shows a lower content of non-labile $\mathrm{C}$ fraction after 18 years of remediation (an increase of alkyl-C in 9.4\%). Therefore, the improved hydrophobicity (3.5 times higher after 
18 years), aromaticity (1.8 times higher after 18 years), humification (3.8 times higher after 18 years), and $\mathrm{C} / \mathrm{N}$ ratio (4 times higher after 18 years) observed for lignite post-mining soil indicates a good ability of that soil type for stabilization of the sequestered $\mathrm{C}$. The following study confirms the influence of the remediation method for soil sequestration. The postmining soil remediated with the addition of sewage sludge showed better properties of sequestered $C$ indicating its longer persistence in the soil. Therefore, the study confirmed that reforestation of post-mining soils improves the quality of $C$ stock. Thus, there is an important role of post-mining soil to mitigate climate changes and lower global heating. However, despite the huge potential of post-mining soil for carbon sequestration, there is currently no prediction for the dynamics of carbon sequestration, SOC stability in lignite, and limestone post-mining soils in the aspect of predicted changes in soil temperatures under global heating and needs further investigation.

Author Contributions: Conceptualization, A.K.; methodology, A.K. and A.G.; validation, A.K.; formal analysis, A.K.; investigation, A.K.; resources, A.K. and A.G.; data curation, A.K.; writingoriginal draft preparation, A.K.; writing—review and editing, A.G. and M.K.; visualization, A.K.; supervision, A.G.; funding acquisition, A.G. and M.K. All authors have read and agreed to the published version of the manuscript.

Funding: The research leading to these results has received funding from the EnviSafeBioC projectcontract No PPI/APM/2018/1/00029/U/001. The project is financed by the Polish National Agency for Academic Exchange (NAWA). The research has been funded by BS/MN-400-301/21 and BS/PB$400 / 301 / 21$.

Conflicts of Interest: The authors declare no conflict of interest.

\section{References}

1. Hüblová, L.; Frouz, J. Contrasting effect of coniferous and broadleaf trees on soil carbon storage during reforestation of forest soils and afforestation of agricultural and post-mining soils. J. Environ. Manag. 2021, 290, 112567. [CrossRef] [PubMed]

2. Kowalska, A.; Grobelak, A.; Almås, Å.R.; Singh, B.R. Effect of Biowastes on Soil Remediation, Plant Productivity and Soil Organic Carbon Sequestration: A Review. Energies 2020, 13, 5813. [CrossRef]

3. Placek-Lapaj, A.; Grobelak, A.; Fijalkowski, K.; Singh, B.R.; Almås, Å.R.; Kacprzak, M. Post-Mining soil as carbon storehouse under polish conditions. J. Environ. Manag. 2019, 238, 307-314. [CrossRef] [PubMed]

4. Sarvade, S.; Upadhyay, V.B.; Kumar, M.; Imran Khan, M. Soil and Water Conservation Techniques for Sustainable Agriculture. In Sustainable Agriculture, Forest and Environmental Management; Jhariya, M.K., Banerjee, A., Meena, R.S., Yadav, D.K., Eds.; Springer: Singapore, 2019; pp. 133-188. [CrossRef]

5. Amoah-Antwi, C.; Kwiatkowska-Malina, J.; Thornton, S.F.; Fenton, O.; Malina, G.; Szara, E. Restoration of soil quality using biochar and brown coal waste: A review. Sci. Total Environ. 2020, 722, 137852. [CrossRef] [PubMed]

6. Yu, H.; Zha, T.; Zhang, X.; Ma, L. Vertical distribution and influencing factors of soil organic carbon in the Loess Plateau, China. Sci. Total Environ. 2019, 693, 133632. [CrossRef] [PubMed]

7. Manaye, A.; Negash, M.; Alebachew, M. Effect of degraded land rehabilitation on carbon stocks and biodiversity in semi-arid region of Northern Ethiopia. Forest. Sci. Technol. 2019, 15, 70-79. [CrossRef]

8. Roy, E.D.; Willig, E.; Richards, P.D.; Martinelli, L.A.; Vazquez, F.F.; Pegorini, L.; Porder, S. Soil phosphorus sorption capacity after three decades of intensive fertilization in Mato Grosso, Brazil. Agric. Ecosyst. Environ. 2017, 249, 206-214. [CrossRef]

9. Šimanský, V.; Juriga, M.; Jonczak, J.; Uzarowicz, Ł.; Stępień, W. How relationships between soil organic matter parameters and soil structure characteristics are affected by the long-term fertilization of a sandy soil. Geoderma 2019, 342, 75-84. [CrossRef]

10. Mukhopadhyay, S.; Masto, R.E. Comparative evaluation of Cassia siamea and Albizia lebbeck for their potential to recover carbon and nutrient stocks in a chronosequence post-mining site. CATENA 2022, 208, 105726. [CrossRef]

11. Dignac, M.F.; Derrien, D.; Barre, P.; Barot, S.; Cécillon, L.; Chenu, C.; Chevallier, T.; Freschet, G.T.; Garnier, P.; Guenet, B.; et al. Increasing soil carbon storage: Mechanisms, effects of agricultural practices and proxies. A review. Agron. Sustain. Dev. 2017, 37, 1-27. [CrossRef]

12. Blume, H.-P.; Brümmer, G.W.; Horn, R.; Kandeler, E.; Kögel-Knabner, I.; Kretzschmar, R.; Stahr, K.; Wilke, B.-M. Schefer/Schachtschabel Lehrbuch der Bodenkunde; Springer Spektrum: Berlin/Heidelberg, Germany, 2016; Volume 16, ISBN 978-3-662-49960-3.

13. Batjes, N.H. Harmonized soil property values for broad-scale modelling (WISE30sec) with estimates of global soil carbon stocks. Geoderma 2016, 269, 61-68. [CrossRef]

14. Kanzler, M.; Böhm, C.; Freese, D. The development of soil organic carbon under young black locust (Robinia pseudoacacia L.) trees at a post-mining landscape in eastern Germany. New For. 2021, 52, 47-68. [CrossRef] 
15. Fox, J.F.; Campbell, J.E.; Acton, P.M. Carbon Sequestration by Reforesting Legacy Grasslands on Coal Mining Sites. Energies 2020, 13, 6340. [CrossRef]

16. Egnér, H.; Riehm, H.; Domingo, W.R. Untersuchungen uber die chemische Bodenanalyse als Grundlage fur die Beurteilung des Nährstoffzustandes der Böden. II: Chemische Extraktionsmethoden zur Phosphor- und Kaliumbestimmung. Kungliga Lantbrukshögskolans Annaler 1960, 26, 199-215.

17. Li, Z.; Huang, M.; Luo, N.; Wen, J.; Deng, C.; Yang, R. Spectroscopic study of the effects of dissolved organic matter compositional changes on availability of cadmium in paddy soil under different water management practices. Chemosphere 2019, 225, 414-423. [CrossRef] [PubMed]

18. Guggenberger, G.; Zech, W.; Haumaier, L.; Christensen, B.T. Land-use effects on the composition of organic matter in particlesize separates of soils: II. CPMAS and solution 13C NMR analysis. Eur. J. Soil Sci. 1995, 46, 147-158. [CrossRef]

19. Spaccini, R.; Mbagwu, J.S.C.; Conte, P.; Piccolo, A. Changes of humic substances characteristics from forested to cultivated soils in Ethiopia. Geoderma 2006, 132, 9-19. [CrossRef]

20. Abakumov, E.; Lodygin, E.; Tomashunas, V. 13C NMR and ESR Characterization of Humic Substances Isolated from Soils of Two Siberian Arctic Islands. Int. J. Ecol. 2015, 2015, 390591. [CrossRef]

21. Sun, X.; Tang, Z.; Ryan, M.G.; You, Y.; Sun, O.J. Changes in soil organic carbon contents and fractionations of forests along a climatic gradient in China. For. Ecosyst. 2019, 6, 1-12. [CrossRef]

22. Helfrich, M.; Ludwig, B.; Buurman, P.; Flessa, H. Effect of land use on the composition of soil organic matter in density and aggregate fractions as revealed by solid-state 13C NMR spectroscopy. Geoderma 2006, 136, 331-341. [CrossRef]

23. Mielnik, L.; Hewelke, E.; Weber, J.; Oktaba, L.; Jonczak, J.; Podlasiński, M. Changes in the soil hydrophobicity and structure of humic substances in sandy soil taken out of cultivation. Agric. Ecosyst. Environ. 2021, 319, 107554. [CrossRef]

24. Li, S.; Lu, J.; Liang, G.; Wu, X.; Zhang, M.; Plougonven, E.; Wang, Y.; Gao, L.; Abdelrhman, A.A.; Song, X.; et al. Factors governing soil water repellency under tillage management: The role of pore structure and hydrophobic substances. Land Degrad. Dev. 2021, 32, 1046-1059. [CrossRef]

25. Piccolo, A.; Mbagwu, J.S.C. Role of Hydrophobic Components of Soil Organic Matter in Soil Aggregate Stability. Soil Sci. Soc. Am. J. 1999, 63, 1801. [CrossRef]

26. Lichner, L.; Hallett, P.D.; Feeney, D.S. Field measurement of soil water repellency and its impact on water flow under different vegetation. Biologia 2007, 62, 537-541. [CrossRef]

27. Wang, X.; Teng, Y.; Ren, W.; Han, Y.; Wang, X.; Li, X. Soil bacterial diversity and functionality are driven by plant species for enhancing polycyclic aromatic hydrocarbons dissipation in soils. Sci. Total Environ. 2021, 797, 149204. [CrossRef] [PubMed]

28. Kushwah, S.K.; Dotaniya, M.L.; Upadhyay, A.K. Assessing Carbon and Nitrogen Partition in Kharif Crops for Their Carbon Sequestration Potential. Natl. Acad. Sci. Lett. 2014, 37, 213-217. [CrossRef]

29. Nguyen, T.B.; Shima, K. Composting of Sewage Sludge with a Simple Aeration Method and its Utilization as a Soil Fertilizer. Environ. Manag. 2019, 63, 455-465. [CrossRef]

30. Singh, P.; Ghosh, A.; Kumar, S.; Chahar, S.; Pradhan, S.; Jat, S. Carbon dynamics of reclaimed coal mine soil: A chronosequence study in the Gevra mining area, Korba, Chhattisgarh, India. Carbon Dynamics. Authorea. 2020. [CrossRef]

31. Placek, A.; Grobelak, A.; Hiller, J.; Stepień, W.; Jelonek, P.; Jaskulak, M.; Kacprzak, M. The role of organic and inorganic amendments in carbon sequestration and immobilization of heavy metals in degraded soils. J. Sustain. Dev. Energy Water Environ. Syst. 2017, 5, 509-517. [CrossRef]

32. Nobile, C.M.; Bravin, M.N.; Becquer, T.; Paillat, J.-M. Phosphorus sorption and availability in an andosol after a decade of organic or mineral fertilizer applications: Importance of $\mathrm{pH}$ and organic carbon modifications in soil as compared to phosphorus accumulation. Chemosphere 2020, 239, 124709. [CrossRef] [PubMed]

33. Xu, S.; Zhao, Q.; Qin, C.; Qin, M.; Lee, J.; Li, C.; Li, Y.; Yang, J. Effects of vegetation restoration on accumulation and translocation of heavy metals in post-mining areas. Land Degrad. Dev. 2020, 11, 397. [CrossRef]

34. Hu, Y.-L.; Niu, Z.-X.; Zeng, D.-H.; Wang, C.-Y. Soil Amendment Improves Tree Growth and Soil Carbon and Nitrogen Pools in Mongolian Pine Plantations on Post-Mining Land in Northeast China. Land Degrad. Dev. 2015, 26, 807-812. [CrossRef]

35. Wu, M.; Pang, D.; Chen, L.; Li, X.; Liu, L.; Liu, B.; Ma, L. Chemical composition of soil organic carbon and aggregate stability along an elevation gradient in Helan Mountains, northwest China. Ecol. Indic. 2021, 131, 108228. [CrossRef]

36. Murano, H.; Suzuki, K.; Kayada, S.; Saito, M.; Yuge, N.; Arishiro, T.; Watanabe, A.; Isoi, T. Influence of humic substances and iron and aluminum ions on the sorption of acetamiprid to an arable soil. Sci. Total Environ. 2017, 615, 1478-1484. [CrossRef] [PubMed]

37. Fontaine, S.; Barot, S.; Barré, P.; Bdioui, N.; Mary, B.; Rumpel, C. Stability of organic carbon in deep soil layers controlled by fresh carbon supply. Nature 2007, 450, 277-280. [CrossRef]

38. Laudicina, V.A.; Novara, A.; Barbera, V.; Egli, M.; Badalucco, L. Long-Term Tillage and Cropping System Effects on Chemical and Biochemical Characteristics of Soil Organic Matter in a Mediterranean Semiarid Environment. Land Degrad. Dev. 2015, 26, 45-53. [CrossRef]

39. Miller, J.J.; Owen, M.L.; Yang, X.M.; Drury, C.F.; Reynolds, W.D.; Chanasyk, D.S.; Naeth, M.A. Long-term cropping and fertilization influences soil organic carbon, soil water repellency, and soil hydrophobicity. Can. J. Soil Sci. 2020, 100, 1-11. [CrossRef]

40. Olorunfemi, I.; Ogunrinde, T.; Fasinmirin, J. Soil Hydrophobicity: An Overview. J. Sci. Res. Rep. 2014, 3, 1003-1037. [CrossRef]

41. Song, E.; Goyne, K.W.; Kremer, R.J.; Anderson, S.H.; Xiong, X. Certain Soil Surfactants Could Become a Source of Soil Water Repellency after Repeated Application. Nanomaterials 2021, 11, 2577. [CrossRef] 
42. Di, X.; Dong, H.; An, X.; Tang, H.; Xiao, B. The effects of soil sand contents on characteristics of humic acids along soil profiles. Acta Geochim. 2016, 35, 251-261. [CrossRef]

43. Sarkar, B.; Mukhopadhyay, R.; Ramanayaka, S.; Bolan, N.; Ok, Y.S. The role of soils in the disposition, sequestration and decontamination of environmental contaminants. Philos. Trans. R. Soc. 2021, 376, 20200177. [CrossRef] [PubMed]

44. Placek, A.; Grobelak, A.; Kacprzak, M. Improving the phytoremediation of heavy metals contaminated soil by use of sewage sludge. Int. J. Phytoremediation 2016, 18, 605-618. [CrossRef] [PubMed]

45. Lipczynska-Kochany, E. Humic substances, their microbial interactions and effects on biological transformations of organic pollutants in water and soil: A review. Chemosphere 2018, 202, 420-437. [CrossRef] [PubMed]

46. Pinos, N.Q.; Louro Berbara, R.L.; Elias, S.S.; van Tol de Castro, T.A.; García, A.C. Combination of Humic Substances and Arbuscular Mycorrhizal Fungi Affecting Corn Plant Growth. J. Environ. Qual. 2019, 48, 1594-1604. [CrossRef]

47. Guo, X.-X.; Liu, H.; Wu, S.-B. Humic substances developed during organic waste composting: Formation mechanisms, structural properties, and agronomic functions. Sci. Total Environ. 2019, 662, 501-510. [CrossRef] [PubMed]

48. Maji, D.; Misra, P.; Singh, S.; Kalra, A. Humic acid rich vermicompost promotes plant growth by improving microbial community structure of soil as well as root nodulation and mycorrhizal colonization in the roots of Pisum sativum. Appl. Soil Ecol. 2017, 110, 97-108. [CrossRef]

49. Gerke, J. Concepts and Misconceptions of Humic Substances as the Stable Part of Soil Organic Matter: A Review. Agronomy 2018, 8,76. [CrossRef]

50. Zhang, B.; Peng, X.H.; Zhao, Q.G.; Hallett, P.D. Eluviation of dissolved organic carbon under wetting and drying and its influence on water infiltration in degraded soils restored with vegetation. Eur. J. Soil Sci. 2004, 55, 725-737. [CrossRef]

51. Rumpel, C.; Knicker, H.; Kögel-Knabner, I.; Skjemstad, J.O.; Hüttl, R.F. Types and chemical composition of organic matter in reforested lignite-rich mine soils. Geoderma 1998, 86, 123-142. [CrossRef] 